\title{
Desamortización y devolución de bienes durante el Trienio Liberal: Cuenca
}

\author{
Manuel Gesteiro Araujo
}

\begin{abstract}
RESUMEN ABSTRACT
A la luz de fuentes documentales inéditas se analiza la dasamortización eclesiástica durante el Trienio liberal en la proviricia y ciudad de

Cuenca.

PALABRAS CLAVE Trienio liberal. Desamortización. Cuenca.

By the guiding light of unpublished documents, it is analysed the sale of ecclesiastical properties during the Liberal Triennium in the city and province of Cuenca.

KEYWORD

Brotherhoods. Liberal Triennium. Sale of ecclesiastical properties. Cuenca.
\end{abstract}

Germán Rueda define la Desamortización, en sentido amplio, como un largo proceso de más de siglo y medio de duración (1766-1924) en el que bienes vinculados y amortizados pasaron a ser libres. Desvinculación y desamortización fueron, según Tomás y Valiente, las condiciones necesarias e ineludibles de la revolución liberal y con ella del tránsito de la sociedad estamental a la sociedad de clases ${ }^{1}$. La desamortización ha sido un tema que ha llamado poderosamente la atención de historiadores y geógrafos desarrollándose numerosos estudios en ámbitos regionales, provinciales, comarcales, locales, etc., pero la mayor parte de las investi-

\footnotetext{
1 Rueda Hernanz, G. La desamortización en España. Un balance (1766-1924). Madrid, Cuadernos de Historia, 38. Arco Libros, 1997, págs. 9-10.
} 
gaciones se han centrado en las etapas de Mendizábal-Espartero (eclesiástica) y de Madoz (civil). Menos atención han recibido otras fases como las de Godoy, José I, Cortes de Cádiz o el Trienio Liberal, quizás por la menor importancia de las ventas, aunque también por una mayor dificultad para acceder a las fuentes documentales.

Entre los trabajos con carácter regional sobre la desamortización durante el Trienio Liberal los más importantes son los de Brines Blasco sobre el País Valenciano, de González Molina en Andalucía y de Martín Martín en Extremadura ${ }^{2}$. De carácter local o comarcal los de Martínez Martín sobre la villa de Madrid, Mateos Rodríguez sobre la comarca de Sanabria (Zamora) y Gomila Casoliva sobre las desamortizaciones del Trienio y Mendizábal en la isla de Menorca. El estudio de las desamortizaciones en la provincia de Cuenca ha sido realizado por González Marzo. La de Mendizábal en 1985, ampliada con dos artículos uno sobre los compradores en 1988 y otro sobre la venta de censos y arrendamientos en 1989 y la de Madoz en 1993. Feijoó Gómez publicó en 1990 un trabajo sobre la desamortización en Castilla-La Mancha, uno de cuyos capítulos se dedica a la provincia de Cuenca. Sobre la desamortización del Trienio Liberal en esta provincia únicamente conocemos un trabajo de García Moratalla (1992-93) sobre la venta de un convento en el pueblo de Villanueva de la Jara ${ }^{3}$.

2 Brines Blasco, J. «Deuda y desamortización durante el Trienio Liberal» en Moneda y Crédito, n. ${ }^{\circ} 124,1973$, págs. 51-67. Brines Bl.ASco, J. La desamortización eclesiástica en el País Valenciano durante el Trienio Constitucional. Valencia, Universidad de Valencia, Secretariado de publicaciones, 1979, 252 págs. González de Molina NAvarRo, M. «La devolución de Bienes Nacionales vendidos en 1820-23. La continuidad de la desamortización del Trienio Liberal. El caso de Granada" en III Coloquio de Historia de Andalucía, 1983. González de Molina Navarro, M. «Estancamiento agrario y desamortización en Andalucía (1820-23) en Agricultura y Sociedad, n. ${ }^{\circ} 30,1984$, págs. 169-197. González de Molina Navarro, M. Desamortización, Deuda Pública y crecimiento económico. Andalucia 1820-23. Diputación Provincial. Granada, 1985, 443 págs. GonzÁlEZ dE MOLINA NAVARRO, M. «Urgencias hacendísticas y devolución de los bienes nacionales vendidos en Andalucía durante el Trienio Liberal (1834-1855)" en Anuario de Historia Contemporánea, n. ${ }^{\circ} 11,1984$, págs. 99-157. GonZÁlEZ DE MolinA NAVARRO, M. «La desamortización eclesiástica en el Trienio Liberal (1820-1823). Un primer acercamiento a los datos generales» en Estudios de Historia Social,I n. ${ }^{\circ} 37-37,1986$, págs. 141-148. GonzÁlez dE Molina NavarRo, M. «Consecuencias sociales y económicas de la desamortización del trienio liberal en Granada y Almería” en Anuario de Historia Moderna y Contemporánea, n. ${ }^{\circ} 7,1980$, págs. 155-186. MARTín MARTín, T. «La desamortización en Extremadura. El Trienio Liberal» en Revista de Estudios Extremeños, 1975, XXXI, págs. 29-44

3 MARTínez MARTín, J. "La desamortización eclesiástica en la villa de Madrid durante el trienio constitucional» en Desamortización y Hacienda Pública. 1986, vol. 2 págs. 357-376. Madrid. MATEos Rodríguez, M. A. «La desamortización en la comarca de Sanabria durante el Trienio Constitucional (1820-1823) en Desamortización y Hacienda Pública. 1986, vol. I, pags. 427-454. Madrid. Gomila Casoliva, J. M. «La desamortización eclesiástica en Menorca (1820-45)» en Revista Menorca, 1976, n. ${ }^{\circ}$ 67, págs. 36-173. GonzÁLEZ MARzo, F. (1985): La desamortización de la tierra 
La desamortización del Trienio se inserta en un desarrollo que además de recoger leyes anteriores sirvió también de antecedente a la de Mendizábal. En 1820, con la restauración de la constitución de 1812, se pusieron en vigencia las leyes revolucionarias promulgadas en las Cortes de Cádiz, algunas de las cuales incluso recogían normas promulgadas en la época de José I, por ejemplo, el Decreto de 17 de junio de 1812 dispuso la enajenación de los bienes de las comunidades eclesiásticas extinguidas o reformadas por los invasores ${ }^{4}$, el Decreto de 13 de septiembre de 1813 según el cual serían bienes nacionales enajenables los de jesuitas, órdenes militares, conventos arruinados y suprimidos en $1802^{5}$. Además el Decreto de $1 .^{\circ}$ de octubre de 1820 que supuso, según Vicens, la rehabilitación del citado decreto de $1812^{6}$. González Molina afirma que son mínimas las diferencias entre el Decreto de 9 de agosto de 1820 y el de 19 de febrero de 1836 por los que se pusieron en marcha, respectivamente, ambas desamortizaciones?.

Durante el Trienio se realizó el primer ensayo general del proceso desamortizador del siglo XIX español ${ }^{8}$. En marzo de 1820 , se decretó la extinción del Tribunal del Santo Oficio y un Decreto del 9 de agosto del mismo año ponía en marcha la desamortización de los bienes de esta institución e iniciaba la desamortización del trienio. La Ley de 1 de septiembre del mismo año iniciaba las ventas de las propiedades de los jesuitas y el

eclesiástica en la provincia de Cuenca. Diputación Provincial. Cuenca, 162 págs. González MARZO, F. «Los beneficiarios del proceso desamortizador en la provincia de Cuenca (1836-45) en 1 Congreso de Historia de Castilla-La Mancha. 1988, Tomo IX págs. 85-92. GonzÁlez MARzo, F. "Redención y venta de censos y arrendamientos en la provincia de Cuenca durante la desamortización de Mendizábal (1836-1845)" en Revista Cuenca, 1989, n. ${ }^{\circ} 33$ págs. 101-113. González MARzo, F. La desamortización de Madoz en la provincia de Cuenca (1855-66). Cuenca, Diputación Provincial, 1993, 462 págs. Felıoó Gómez, A. La desamortización del siglo xix en Castilla-La Mancha. Junta de Comunidades de Castilla-La Mancha, 1990, 301 págs. García Moratalla, P. J. «Desamortización del convento de Franciscanos observantes de Villanueva de la Jara (Cuenca) en el trienio liberal (1820-1823)" en Anales del Centro de Albacete (UNED). 1992-93, N. ${ }^{\circ}$ 12, págs. 275-291. Las referencias de estas obras pueden consultarse en la bibliografía que se cita al final de la comunicación.

4 VICENS VIVES, J. Historia económica de España, pág. 573

5 BRines, Deuda y desamortización..., o. c., págs. 54-55.

6 VICENS, o. c., pág. 574.

7 GONZÁlez de MOLINA, «Urgencias...», o. c., pág. 101.

8 Con la política desamortizadora, los liberales perseguían varios objetivos que formaban parte de su programa revolucionario: Religiosos, ya que supusieron una reforma del clero y de su función social. Como ejemplos podemos considerar la supresión de los jesuitas, favorecer la secularización, prohibir la fundación de conventos, suprimir conventos y reunir a los miembros de las comunidades con menos de 24 sacerdotes en los conventos más próximos de la misma orden, etc. Políticos, ya que se buscaba vincular a las clases medias con el régimen constitucional a través de la compra de bienes desamortizados. Económicos, dado que la puesta en venta de tierras forma parte de unas medidas de política agraria que pretendía acabar con el estancamiento de los 
día 3 se publicó el primer decreto en el que se establecía el reglamento para la venta de las fincas consignadas al Crédito Público. El Decreto de 1 de octubre de 1820, llamado «de monacales», complementaba el del 9 de agosto y establecía la supresión de monasterios, órdenes monacales, canónigos regulares de San Benito, San Agustín y Premonstratenses, órdenes militares, San Juan de Jerusalén y Hospitalarios. Sólo se salvaban de la exclaustración los escolapios y misioneros de Asia y los conventos que contaran con más de 24 sacerdotes o 12 si no había más que uno en cada localidad ${ }^{9}$. La desamortización del trienio fue, por tanto, eminentemente eclesiástica y afectó sobre todo al clero regular masculino ${ }^{10}$, con la excepción del incumplido real Decreto de 29 de junio de 1822 que puso en venta baldíos, realengos propios y arbitrios ${ }^{11}$.

El artículo segundo del real del Decreto de 9 de agosto de 1820 estableció que el pago de los bienes desamortizados se efectuase con cualquier instrumento de deuda pública con o sin interés y en el artículo tercero que no se admitiese el pago en efectivo. Es lógico si se tiene en cuenta que la deuda pública de España se calculaba en unos $14.020 \mathrm{mi}$ Ilones de reales repartidos casi a partes iguales entre la que generaba interés $(48,6 \%)$ y la que no lo hacía $(51,4 \%)^{12}$. Por eso la condición tercera del artículo octavo de la real Orden de 3 de septiembre insiste en que las compras se pagasen indispensablemente en Créditos contra el Estado.

Lâ utilización de deuda pública como instrumento exclusivo de pago dio mayores oportunidades de compra a los acreedores de la Hacienda por ser prácticamente los únicos poseedores de vales y títulos de la deuda. Por eso puede afirmarse que la desamortización fue un fenómeno urbano, no tanto por la localización de los bienes desamortizados sino por la residencia de los compradores y por el origen de los recursos utilizados para efectuarlas. Los poseedores de vales reales y de papeles de crédito, procedentes de los abastecimientos al ejército, eran las clases medias y la burguesía urbana así como los campesinos acomodados. Residían en las capitales de provincia o en los pueblos importantes de las mismas y efec-

\footnotetext{
bienes de manos muertas. Fiscales, ya que la liquidación de la deuda pública, creada sobre todo durante la guerra contra Napoleón, para solucionar los problemas financieros de un Estado nuevo en tase de consolidación.

9 BRines, La desamortización..., o. c., pág. 6.

10 González de Molina, Desamortización..., o. c., pág. 212.

11 Martín Martín, «La desamortización...», o. c., pág. 32. HerR, R. «El significado de la desamortización en España" en Moneda y Crédito, 1974, n. ${ }^{\circ}$ 131, págs.57-94.
} 
tuaron las compras tanto en su lugar de residencia como en diferentes pueblos de sus provincias ${ }^{13}$.

La fuente que vamos a utilizar es un cuadernillo de la Contaduría de Arbitrios de Amortización que hemos localizado en una caja con la signatura SAN 839 del fondo Desamortización del Archivo Histórico Provincial de Cuenca. Se trata de un registro de bienes abierto en 1835 con el fin de dar posesión de nuevo a las personas que los compraron en la desamortización eclesiástica del Trienio Liberal en cumplimiento del Real Decreto de 3 de septiembre de 1835. Hay dos documentos, en el primero están los datos relativos a 34 propiedades vendidas entre $1821-23$ y se ha incluido como apéndice de esta comunicación. La información de cada finca es completísima, únicamente falta el valor de tasación. Figura la procedencia, localización, rematante y domicilio, forma y documentos de pago, partido, juez, escribano, etc. También figura la fecha en que se reintegran a los respectivos compradores. En la Gaceta de Madrid y en algunos protocolos notariales del Archivo Provincial de Cuenca hemos localizado el valor de tasación de la mayor parte de las fincas que figuran en la citada relación.

El segundo documento es una clasificación general de la clase de créditos que se entregaron para el pago de cada finca y que en la última hoja dice «continua en el libro segundo» lo que nos permite deducir que fueron más las fincas desamortizadas y devueltas. Pese a la búsqueda realizada, no hemos podido localizar este «segundo libro». Además, el conde de Toreno dice que las fincas rematadas en la provincia de Cuenca ascendieron a 3,6 millones de reales ${ }^{14} y$ en estos documentos solamente se registran por la cantidad de 1, 3, es decir, un tercio del importe total de los remates. En la Gaceta de Madrid y en los Boletines del Crédito Público hemos podido comprobar que, efectivamente, fueron muchas más las propiedades que salieron a subasta.

12 Brines, La desamortización eclesiástica..., 0. c., pág. 228.

13 LISTA dE ARBITRIOS PARA AmORTIZACIÓN DE LA DEUdA.- 1. Bienes pertenecientes a las temporalidades de los jesuitas.- $2{ }^{\circ}$ Los predios rústicos y urbanos de las encomiendas y de los maestrazgos de las órdenes militares, incluso la de $\mathrm{S}$. Juan de Jerusalén, vacantes y que vacaren por muerte de los actuales poseedores, quedando nulas las gracias de las supervivencias.- $3 .^{\circ}$ Las alhajas y fincas llamadas de la Corona, y las existentes en los sitios Reales, no necesarias para el recreo de las augustas Personas de SS. MM. y AA.- $4 .^{\circ}$ La mitad de los baldíos y realengos.- $5 .^{\circ}$ Los estados de la última duquesa de Alba y demás que se incorporen a la Nación.- $6{ }^{\circ}$ El valle de Alcudia.- $7 .^{\circ}$ Los bienes estables pertenecientes a la Inquisición.- $8^{\circ}$ Los bienes de monacales suprimidos y los de los demás conventos regulares extinguidos por la reforma.- $9 .^{\circ}$ El valor de las fábricas nacionales de paños de Guadalajara, paños de Brihuega, cristales de S. Ildefonso y sedas de Talavera.- $10 .^{\circ}$ Los edificios nacionales no necesarios en Madrid.- Real Orden de 19 de Noviembre de 1820 regulando la Deuda Pública. Citada por BRINES, La desamortización eclesiástica..., o. c., pág. 230. 
Remates de la provincia de Cuenca en la Gaceta de Madrid

\begin{tabular}{rrlrr}
\hline GACETA & FECHA & \multicolumn{1}{c}{ PROCEDENCIA } & TASACIÓN & REMATE \\
\hline 199 & $14-7-1821$ & Inquisición & 142.192 & $158.847-22$ \\
243 & $1-12-1821$ & Inquisición & 5.363 & 5.363 \\
48 & $16-2-1822$ & & 139.700 & 140.000 \\
132 & $10-5-1822$ & Conventos y Monasterios & 66.859 & 67.789 \\
182 & $24-6-1822$ & Conventos y Monasterios & 347.640 & 389.862 \\
255 & $31-8-1822$ & Conventos y Monasterios & $155.313-19$ & 278.238 \\
342 & $22-11-1822$ & Conventos y Monasterios & 41.549 & 41.549 \\
377 & $27-12-1822$ & Monasterios & 19.506 & 19.506 \\
& & Obras pías & 2.250 & 6.600 \\
& & Monasterios & 533.536 & 622.918 \\
18 & $18-1-1823$ & Obras pías & 450 & 950 \\
& & Monasterios & 188.607 & 403.075 \\
& & Obras pías & 9.984 & 9.984 \\
48 & $14-2-1823$ & Monasterios & 18.295 & 30.000 \\
& & Obras pías & 14.784 & 21.929 \\
& & Monasterios & 364.802 & 379.228 \\
\hline Totales & & & $2.050 .560-19$ & $2.575 .838-22$ \\
\hline
\end{tabular}

González Marzo estima que las ventas del Trienio pueden ser la causa de la escasa o nula participación de algunos conventos en la desamortización de Mendizábal en la provincia de Cuenca ${ }^{15}$. En la Gaceta de Madrid hemos localizado remates por valor de 2,6 millones de reales realizados en esta provincia hasta febrero de 1823. Es posible que en los meses que median hasta que se decretó la suspensión de las ventas se alcanzasen los 3,6 millones que cita Toreno o que hubiese una cierta lentitud en la publicación oficial de los remates.

Según González Molina ${ }^{16}$ las ventas se iniciaron en el mes de marzo de 1821 y las últimas tuvieron lugar en la provincia de Cádiz en junio de 1823 ya que la invasión francesa se había producido en abril del mismo año. En Cuenca, las primeras ventas conocidas son de julio de 1821 y fueron bienes procedentes del suprimido Tribunal de la Inquisición y las últimas en 3 de mayo de 1823. El ritmo de ventas fue bastante uniforme en Cuenca ya que de los 34 remates conocidos, 9 se produjeron en seis meses de 1821, 17 en 1822 y 8 en cinco meses de 1823.

La mayoría de las fincas $(72,3 \%)$ se pagaron con créditos sin interés y fue prácticamente nulo el pago en efectivo, seguramente unas pequeñas

14 Citado por GonzÁlez DE MOLINA, «La desamortización...», o. c., pág. 144.

15 GonzÁlez Marzo, La desamortización..., o. c., pág. 35.

16 GonZÁleZ DE MOLINA «La desamortización...», o. c., pág. 142. 
cantidades para completar el total de algún remate. En ninguno de los casos conocidos se utilizó la compra a plazos. La mayor parte de los lotes pueden ser calificados como medianos, a juzgar por su valor de remate, ya que ninguno superó el medio millón de reales y la mayor parte superaron los 10.000 .

Lotes clasificados por su valor de remate en Cuenca

\begin{tabular}{cccc}
\hline VALOR & LOTES & \multicolumn{1}{c}{ REALES } & $\%$ \\
\hline$<1.000$ & 0 & 0 & 0,0 \\
$1.000-9.999$ & 9 & $51.940-21-1 / 2$ & 4,1 \\
$10.000-49.999$ & 19 & $494.146-18-1 / 2$ & 38,8 \\
$50.000-99.999$ & 4 & $295.810-12$ & 23,3 \\
$>100.000$ & 2 & 430.099 & 33,8 \\
\hline Total & 34 & $1.271 .996-18$ & 100,0 \\
\hline
\end{tabular}

El único caso en el que se detallan los nombres de las personas a cuyo favor están expedidos los documentos de crédito es el de Enrique López, vecino de Cuenca, que remató la casa en la que actuaba el Tribunal de la Inquisición en la cantidad de 35.864 reales 7 maravedíes y que pagó con vales y recibos sin interés de los cuales solamente dos, que sumaban 3.610 reales, el $10 \%$ de la compra, estaban expedidos a su nombre ${ }^{17}$. En otros compradores se hace relación de los documentos indicando si son vales o recibos, la fecha de expedición y el importe, pero no el nombre de la persona a la que se libran. También es bastante frecuente que en el registro figure un simple "paga en diferentes documentos o recibos de crédito contra el Estado".

Los bienes de naturaleza urbana más importantes desamortizados en Cuenca capital fueron los procedentes del Tribunal de la Inquisición: cinco

\begin{tabular}{ccccc}
17 & \multicolumn{1}{l}{} \\
\hline DOCUMENTOS APORTADOS POR ENRIQUE LÓPEZ & \\
\hline 1800 & RECIBOS & VALES & PESOS & CUANTÍA \\
1808 & 1 & 5 & 600 & 1.805 \\
1809 & 1 & 6 & 600 & 2.166 \\
1814 & 1 & 4 & 300 & 722 \\
1815 & 8 & 16 & 2.100 & 15.039 \\
1818 & 3 & 5 & 600 & $3.790-17$ \\
Total & 7 & 26 & 1.650 & 12.341 \\
\hline
\end{tabular}


casas, entre ellas la del Tribunal, la del Aicaide y la de la Penitencia, un solar, una cochera, un corral y un horno. Por la Gaceta de Madrid sabemos que también se remató una casa más, contigua a las murallas del castillo ${ }^{18}$. También hubo algunos edificios procedentes de los conventos extinguidos que fueron desamortizados y vendidos y en la población de Uclés destaca la venta de un pozo de nieve con su casa, pertrechos y charcas y un molino harinero situado en el río Bedija a su paso por esta localidad.

El total de tierras desamortizadas fue de 1.620 hectáreas (ha) ${ }^{19}$. Procedían en su mayor parte del clero regular y de la orden militar de Santiago (Uclés), aunque también se vendió una Obra Pía de Ánimas en Cañadajuncosa y una capellanía en la parroquial de Landete: las tierras de ambas instituciones sumaban 64 ha.

El convento de San Pablo, de la orden de Santo Domingo, hoy parador de turismo, está separado del casco histórico de Cuenca por la hoz del Huécar y unido a la ciudad por el puente de San Pablo. En su entorno había 29 almudes en el hocino ${ }^{20}$ de San Pablo, dos huertos: uno contiguo al convento y otro bajo el puente, además de otros dos huertos, uno de 700 eras $^{21}$ de regadío y 3 de secano y otro de 950 eras de regadío y 3 de secano. Según el censo de Floridablanca tenía 20 individuos ordenados in sacris y fue uno de los conventos suprimidos. De este convento fueron vendidas 732,4 ha., casi la mitad de las tierras rematadas, que se encontraban, además de en la capital, en diversos pueblos de la provincia como Huerta de la Obispalía, San Lorenzo de la Parrilla, Fuestesclaras del ChiIlarón y Valdemorillo. Las propiedades rústicas de los mercedarios descalzos, cuyo convento en Cuenca contaba con 28 individuos según Floridablanca, estaban repartidas en diversas localidades: Cuenca, Nohales, Barbalimpia y Villar de Olalla. En total se le desamortizaron 194,68 ha, junto con un covacho y dos casas. A los trinitarios calzados de Nuestra Señora del Remedio se le desamortizaron dos pequeñas propiedades en los municipios de Valdecolmenas y Valdeganga, en total 33 ha. De los franciscanos observantes se vendió un pequeño huerto de 10 celemines perteneciente al convento de Villanueva de la Jara y 123,7 ha en el término de Cañadajuncosa del convento situado en Valera de Abajo. El convento de San Benito de Huete que únicamente contaba con cuatro sacer-

\footnotetext{
1816 de diciembre de 1820.

19 Los almudes los hemos reducido como de 0,32 ha y las fanegas como de 0,64 .

20 Pequeño huerto en una ladera agreste cercano a un río.

21 Tierra muy pequeña destinada a hortalizas o flores.
} 
dotes fue suprimido. Era un gran propietario de tierras y muchas de ellas salieron a subasta, pero solo tenemos noticias del remate de 22,7 ha. en Barajas de Melo y Yuso ${ }^{22}$. En el municipio de Iniesta se subastaron dos casas de labor y 302,6 ha. y una llamada de Matallana junto a 219 ha. de labor pertenecientes al convento de Nuestra Señora de la Loma de Campillo de Altobuey de los agustinos calzados.

Mención aparte merece la Real Casa de Santiago en Uclés. El Priorato de Uclés era uno de los grandes terratenientes de la Mancha y aunque fueron bastantes las tierras que salieron a la venta, solamente tenemos constancia del remate de 229,8 ha. en Uclés, Almendros y Rozalén del Monte y de un huerto cuya superficie no consta en la localidad de residencia del monasterio. Según Revuelta, fueron muy importantes las ventas de la Casa de Santiago de Uclés, muchas de las cuales no fueron controladas por el Crédito Público, aunque sus agentes se incautaron 60.000 reales de ventas realizadas irregularmente que se habían repartido los doce frailes del monasterio ${ }^{23}$.

Los 34 lotes rematados de los que tenemos noticias fueron adquiridos por 22 compradores. Casi todos eran residentes en la provincia de Cuen$\mathrm{ca}$, incluyendo a los de Tarazona y La Roda, que en el Antiguo Régimen pertenecían a esta provincia, uno era de Madrid y otro de Guadalajara aunque éste último cedió su compra a un conquense. La mayor parte de los compradores eran de Cuenca capital y ellos aportaron los 2/3 del importe de los remates. Adquirieron todos los bienes que salieron a subasta en la capital, fundamentalmente inmuebles urbanos, así como los que se vendieron en municipios próximos a la misma Nohales, Villar de Olalla, Chillarón, Fuentesclaras, etc. e incluso en alguno más alejado como San Lorenzo de la Parrilla y Valdemorillo. Los residentes en los pueblos compraron fundamentalmente en su localidad de residencia o en pueblos relativamente cercanos.

Los residentes en Cuenca capital fueron 13 y sus compras ascendieron a 668.724 reales, el $52 \%$ del importe de los remates conocidos. Pertenecían a las clases medias urbanas: comerciantes, rentistas, clérigos, escribanos, etc. Una parte de sus compras la constituyeron los bienes inmuebles - casa, cocheras, corrales, hornos, solares- pero también las tierras

22 Barajas de Yuso es un despoblado situado en la confluencia de los términos de Barajas de Melo, Huelves, Alcázar del Rey, Vellisca y Saceda-Trasierra. LaRRAÑAga y Mendía, J. Cuenca, pág. 362.

23 Revuelta González, M. La política religiosa de los liberales en el siglo XIX. Madrid, CSIC. Escuela de Historia Moderna, 1973, pág. 226. 
ya que adquirieron alrededor de 1.500 almudes por valor de la mitad del importe de lo rematado.

Hemos podido recabar información personalizada sobre algunos de los compradores cuya relación efectuamos. El presbítero don Isidro Calonge, canónigo de la Catedral de Cuenca, compró por valor de 47.514 reales 30 maravedises dos casas, parte de otra y unas tierras: las casas procedían del suprimido convento de mercedarios de Cuenca y las tierras eran 9 parcelas (siete en Cuenca y dos en la vecina localidad de Nohales) que sumaban un total de 47 almudes y 7 celemines ${ }^{24}$. También compró parte del convento de los Agustinos de la localidad. Pagó 36.009 reales 2 mrs. En documentos sin intereses y lo restante con ellos, incluso cedió al tesoro 14 reales y 32 maravedíes que excedian del valor del remate. Le fueron devueltos los días 6 y 8 de agosto de 1835. En la desamortización de Mendizábal efectuó algunas compras ya que en 1843 adquirió una heredad de 88,26 ha. por valor de 60.000 reales en la localidad de Arcas ${ }^{25}$.

Otro canónigo de la Catedral de Cuenca, Manuel Fernández Manrique, remató una de las casas del Tribunal de la Inquisición sita en dicha ciudad. Había sido subastada en 9.393 reales y la adquirió en 20.035 reales 25 maravedíes que pagó con créditos sin interés. Le fue devuelta el 16 de octubre de $1835^{26}$.

El 16 de marzo de 1822 Francisco Sainz de Rozas, comerciante de Cuenca, remató 357 almudes 2 celemines y 2 cuartillos procedentes del Convento de San Pablo de Cuenca situados en el pueblo de Valdemorillo. Se trata de un lote de 86 pequeñas tierras, la media era de unos 4,2 almudes, y el remate alcanzó los 14.000 reales que pagó con créditos, con y sin interés.

Manuel Martínez ${ }^{27}$ compró dos casas que pertenecieron al suprimido convento de Nuestra Señora del Socorro de los agustinos calzados. Las remató en 22.822 reales y pagó con documentos con y sin interés dejando un excedente de 3.655 reales y $91 / 2$ maravedies a favor de la hacienda. Se le dio posesión definitiva el 31 de octubre de 1835. Este vecino de Cuenca también adquirió, en la desamortización de Mendizábal, 124,32 ha. de labor en secano y 500 eras en regadío situadas en Cuenca, Chillarón de Cuenca y Palomera, por un total de 72.179 reales ${ }^{28}$.

24 Crédito Público, n. ${ }^{\circ} 8,16-2-1822$.

25 González MARzo, La desamortización..., o. c., pág. 127

26 AHPC. Escribano Clemente S. de Navalón protocolo 1593, año 1821.

27 Si es Martínez de Rozas se trata de un abogado.

28 González Marzo, La desamortización..., o. c., pág. 140. 
José Martínez de Rozas, que podría ser pariente del anterior, compró una casa con cochera y corral y otro corral, situados todos en la ciudad de Cuenca y procedentes de la Inquisición, por un total de 14.295 reales 25 maravedíes con créditos sin interés. Le fueron devueltos el 12 de diciembre de 1835.

Eugenio Andrés Cano, de profesión escribano, compró dos casas en la ciudad de Cuenca, una procedía de la Inquisición y otra de los carmelitas, por las que pagó 32.025 reales con créditos, con y sin interés, y cedió 7 reales y $19^{1 / 2}$ maravedíes a favor del Crédito Público. Le fueron devueltas el 6 y el 10 de octubre de 1835. La primera de las casas se la cedió a su hija Calixta y en su nombre a Juan de la Cruz Jiménez, presumiblemente su yerno. Juan de la Cruz, según Muñoz y Soliva, era un ganadero y comerciante que en 1845 creó una «Sociedad Familiar» en cuyos locales se daban clases de baile y declamación, se leía la prensa, jugaba al tresillo, etc. ${ }^{29}$. Compró 30,94 ha. de labor y pastizal por la cantidad de 69.670 reales en la desamortización de Mendizábal y actuó como prestamista de otro comprador ${ }^{30}$.

Luis Sainz Martínez, del comercio de la ciudad de Cuenca ${ }^{31}$, compró varias tierras y casas por un total de 230.810 reales de los que pagó 82.172 reales y 11 maravedíes con créditos con interés y lo restante sin él. Tres lotes pertenecían al convento de San Pablo y estaban en Cuenca (dos casas, bodega, solar, 29 almudes de tierra, dos huertos y 1.650 eras de regadío y secano), San Lorenzo de la Parrilla (90 almudes y 2 celemines) y en Fuentesclaras del Chillarón ( 913 almudes y 2 celelemines en 127 tierras). El cuarto era un horno procedente de la Inquisición y se encontraba en la capital. Le fueron devueltos los cuatro el 20 de octubre de 1835. Las compras las efectuó como tutor de Bernardino Sainz, de José Sainz y Marzo y de Valentín del Corral en representación de su esposa Vicenta Marzo. Un Bernardino Sainz compró en la desamortización de Mendizábal 47,5 ha. en el pueblo de Enguidanos por 33.124 reales a través de un intermediario llamado Juan María González y apareció en los censos de electores de la provincia de Cuenca debido a la importancia de sus propiedades ${ }^{32}$.

Los residentes en el espacio rural pertenecian al grupo de campesinos acomodados, algunos de ellos caciques destacados, generalmente

\footnotetext{
Muñoz y Soliva, T. Historia de la ciudad de Cuenca, tomo II, pág. 991. Ibidem págs. 81-82.

AHPC. Clemente S. de Navalón, protocolo 1594 (1823).

GonzÁlez MARzo, La desamortización..., o. c., pág. 148.
} 
vinculados a la explotación de la tierra, e incluso un presbítero. Santiago María Melgarejo ${ }^{33}$ era un labrador, manifiestamente rico del pueblo de $\mathrm{Ca}$ ñadajuncosa que compró un lote de 386 almudes 3 celemines en 16 pedazos, (uno de los cuales tenía 178 almudes), procedente del extinguido convento que los franciscanos observantes de Valera de Abajo poseían en Cañadajuncosa y 16 tierras y un horno procedentes de la Obra Pía de Ánimas de dicha localidad. En total importaron 8.411 reales y 2 maravedíes que pagó con documentos de crédito con y sin interés. Ambas fincas le fueron devueltas el 24 de noviembre de 1835. En 1840 remató en el mismo pueblo una heredad por valor de 2.086 reales ${ }^{34}$.

Manuel Quintero, labrador acomodado de Uclés, remató 2641/2 fanegas en 54 tierras procedentes de la extinguida Real Casa de Santiago y situadas en la localidad de Rozalén del Monte, tasadas en 21.855 reales se remató en 23.982 y pagó con créditos sin interés. Fue devuelta a su comprador el 30 de octubre de 1835. Según González Marzo, este mismo propietario compró en Rozalén del Monte y en Uclés 254,5 ha. por valor de 89.119 reales ${ }^{35}$. González Marzo califica como caciques tanto a Manuel Quintero como al anteriormente citado Santiago Melgarejo ${ }^{36}$.

Del convento de franciscanos observantes de Villanueva de la Jara, cuya desamortización ha sido estudiada por García Moratalla ${ }^{37}$, se subastaron el convento, la iglesia y una huerta por un valor total de 544.486 reales. En la primera subasta, Pascasio Jiménez, vecino de Tarazona de la Mancha, remató la huerta en 19.000 reales pero el convento y la iglesia quedaron sin postor. En una segunda subasta, el mismo comprador, mejoró su postura por la huerta hasta 25.000 reales que pagó en créditos con y sin interés dejando 861 reales y un maravedí y medio de «generosa propina» para el Crédito Público. Se le dio posesión definitiva el 29 de octubre de 1835.

Finalmente, Felipe García, presbítero de La Roda, es el tercer eclesiástico que participó en las compras. Adquirió una casa en su localidad procedente de los trinitarios calzados de Fuensanta. La casa salió a subasta en 7.653 reales y fue rematada en 7.650 pagándose en vales y créditos con y sin interés. Cedió 1.800 reales 15 y medio maravedíes para la Hacienda pública.

33 Ibidem, pág. 73.

34 Ibidem, pág.141.

35 Jbidem, pág. 147

36 GonzÁleZ Marzo, F. "Las elites conquenses del siglo XIX», pág. 262

37 Garcia moratalla, O. C. 
Todas las ventas realizadas durante el Trienio liberal fueron anuladas por un Decreto de la Regencia de 11 de junio de $1823^{38}$. Sin embargo, el 3 de septiembre de 1835, el gobierno de Toreno, con García Herreros como ministro de Gracia y Justicia, publicó un real Decreto por el que se reintegraban a sus compradores los bienes de eclesiásticos rematados durante el Trienio. El proceso y las consecuencias de la restitución de los bienes a sus compradores, si exceptuamos los trabajos de González de Molina para Andalucía ${ }^{39}$, está muy poco estudiado. La restitución a los compradores era una medida absolutamente necesaria ya que la mayoría de las comunidades eclesiásticas habían sido nuevamente suprimidas y en algunas provincias ya se había puesto en marcha la devolución incluso antes de la aprobación y publicación del Real Decreto ${ }^{40}$.

En el caso de la provicia de Cuenca el Director General de la Contaduría de Amortización de Cuenca, por Orden de 21 de septiembre de 1835, inició el proceso de devolución: un proceso muy acelerado porque la primera finca se devolvió el 26 de septiembre y las últimas el 24 de noviembre de 1835.

A partir de las 34 propiedades que fueron devueltas a sus compradores en 1835, podemos extraer las siguientes conclusiones: La mayor parte de los bienes situados en Cuenca capital eran de naturaleza urbana y procedían de la Inquisición y casi todas se efectuaron en créditos sin interés. Además, los compradores pertenecían a las clases medias urbanas (escribanos, comerciantes, eclesiásticos) y labradores acomodados en el ámbito rural. Algunos de ellos también adquirieron tierras en la desamortización de Mendizábal. Finalmente, el valor de los remates fue un $32 \%$ superior al de aquellos bienes cuya tasación hemos podido conocer, mientras que el valor del $96 \%$ de los lotes reınatados se sitúa entre 10.000 y 300.000 reales.

38 González de Molina, «Estancamiento..., o. c. 〈ll>, pág. 104.

39 En las dos obras «Urgencias.... y y «La devolución...» de GONZÁLEZ DE MOLINA.

40 lbidem, págs. 121-122. 


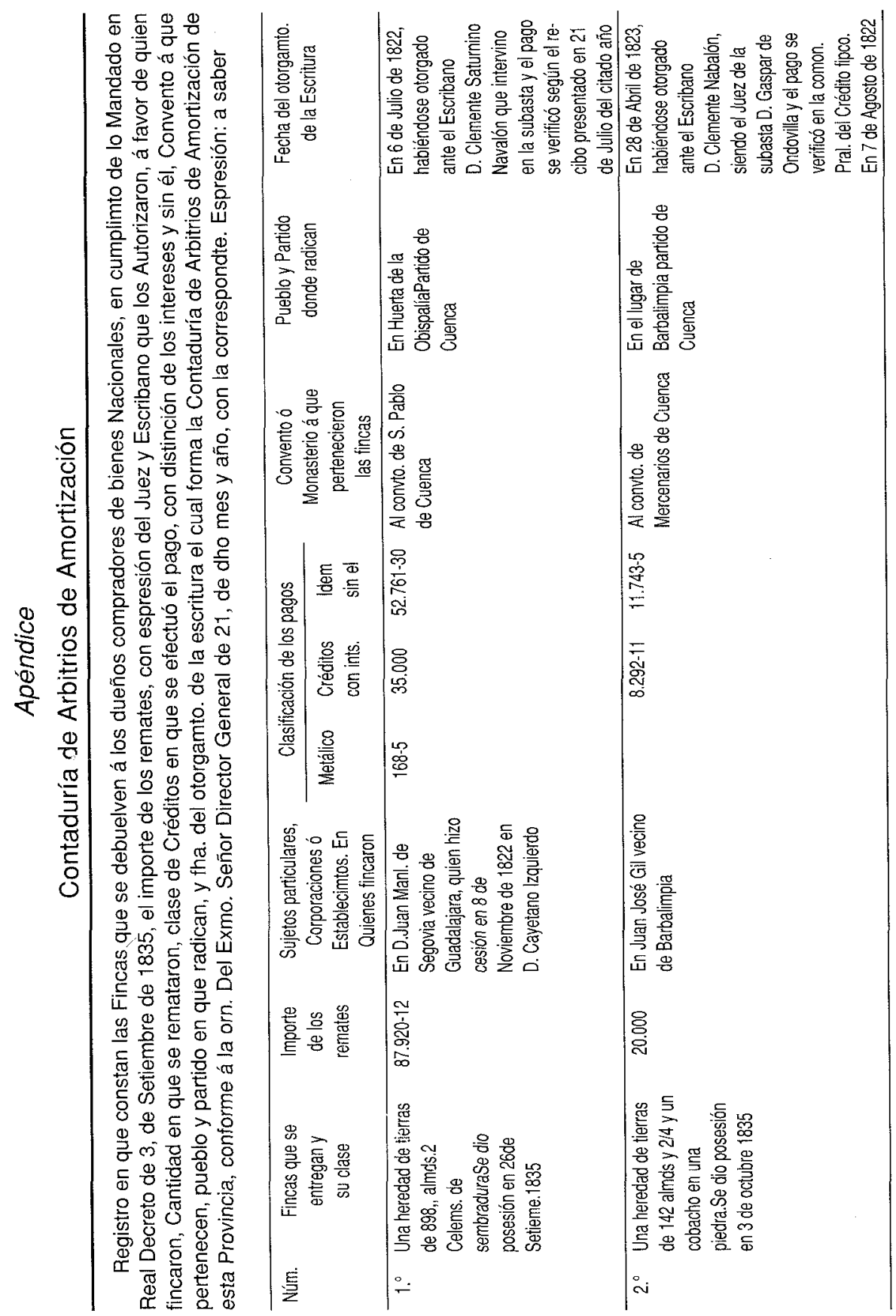




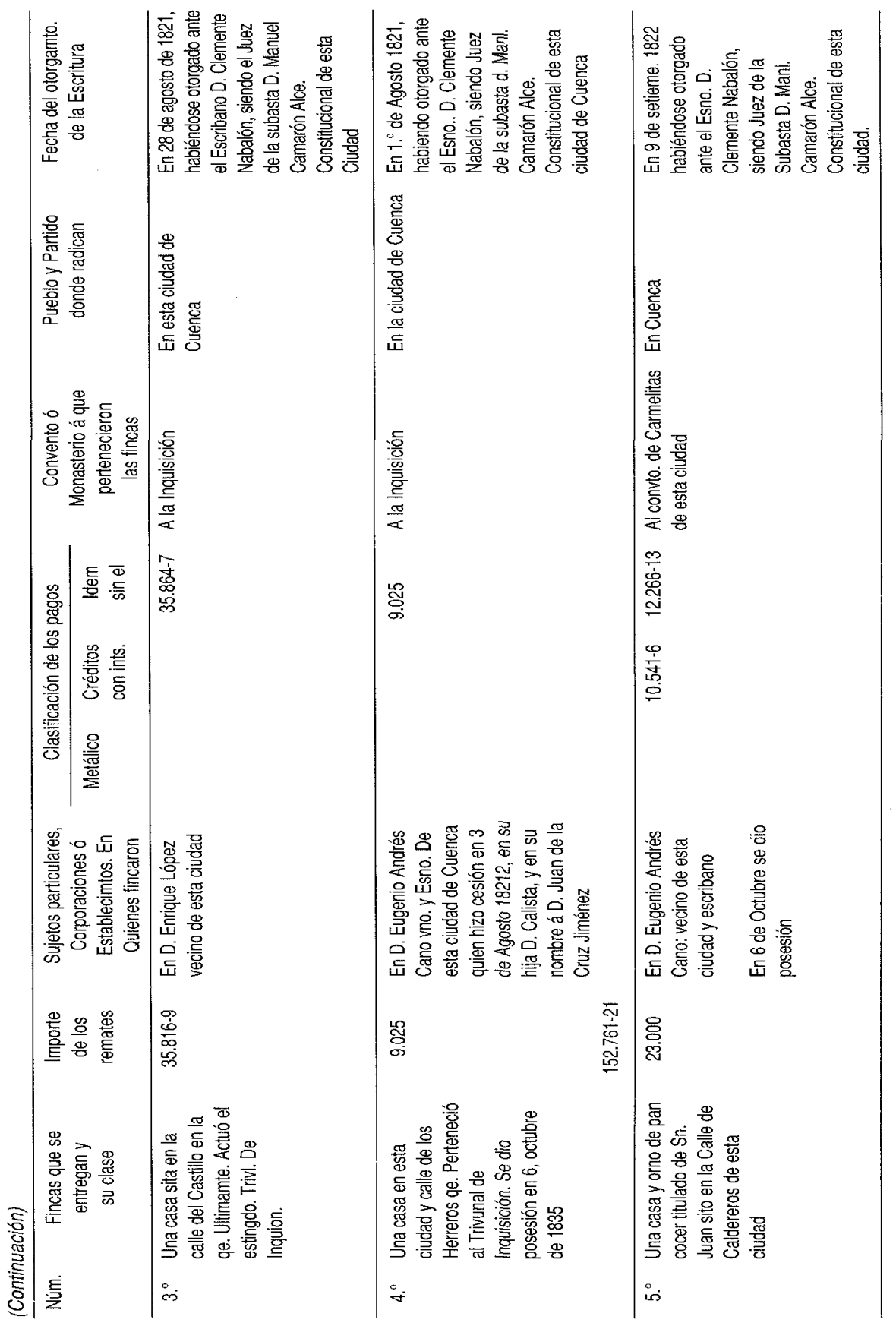



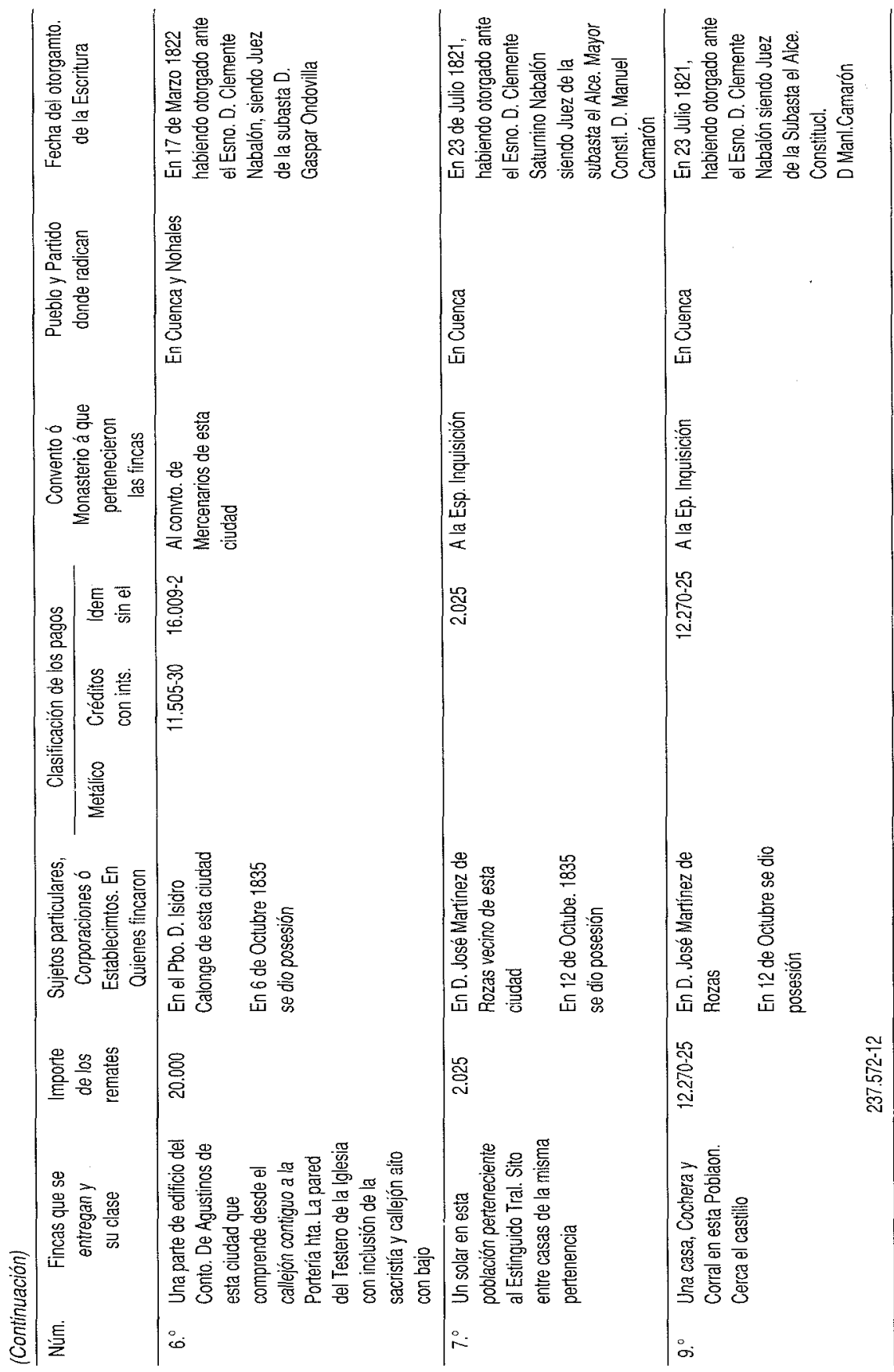


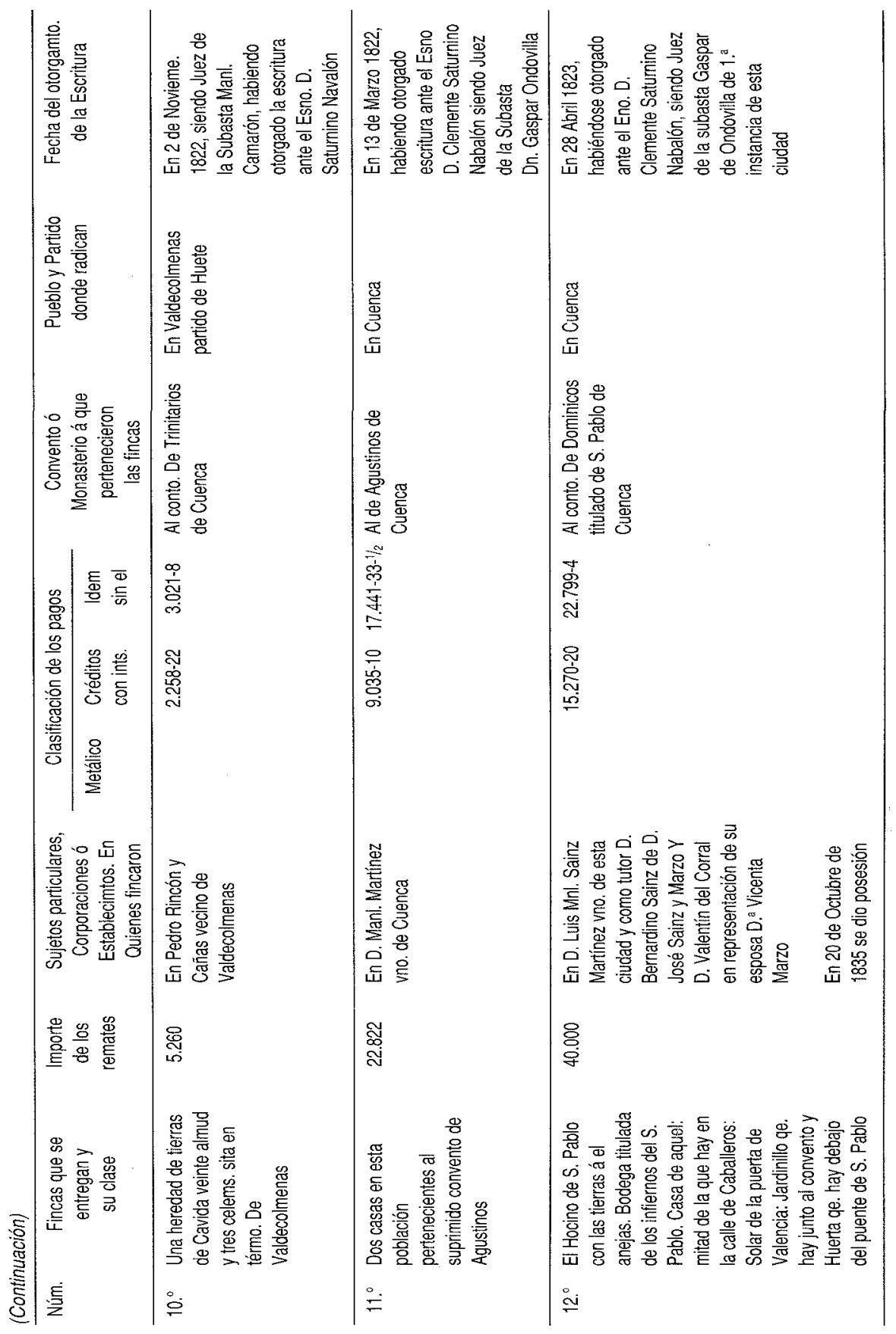




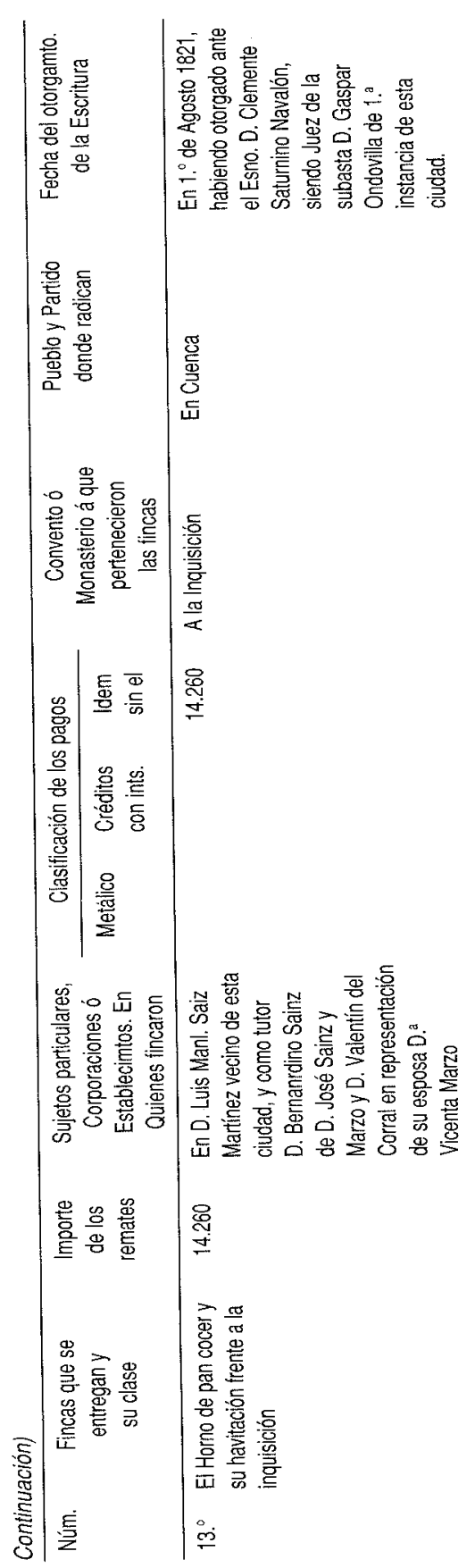

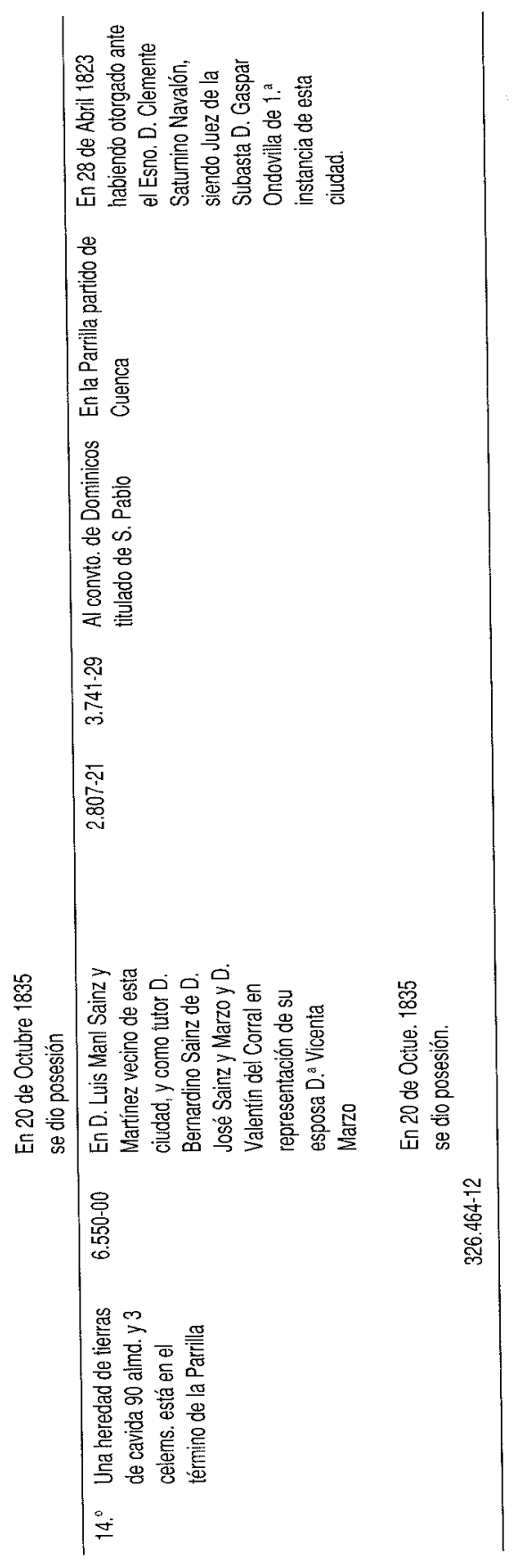

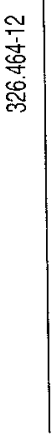



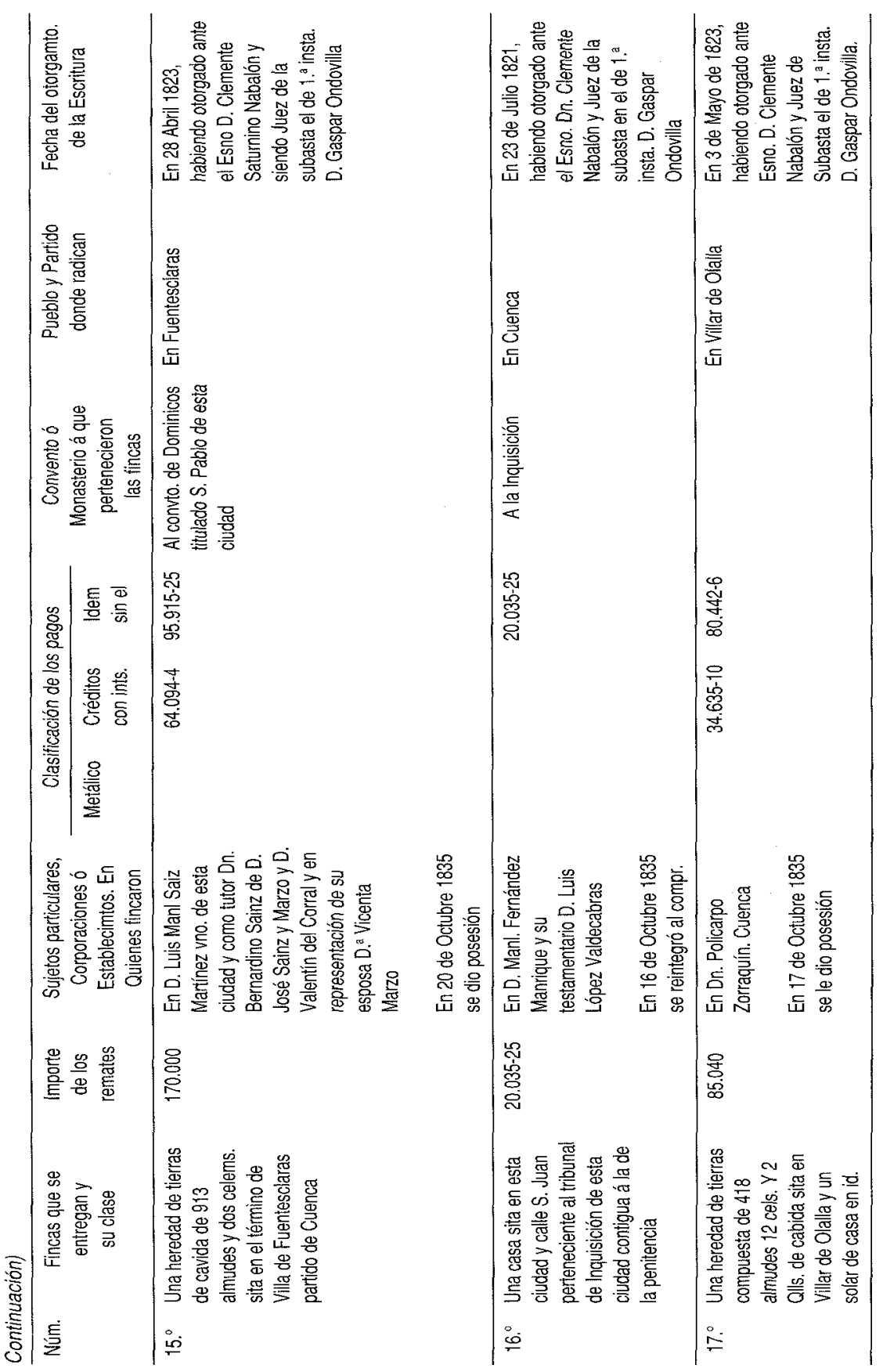

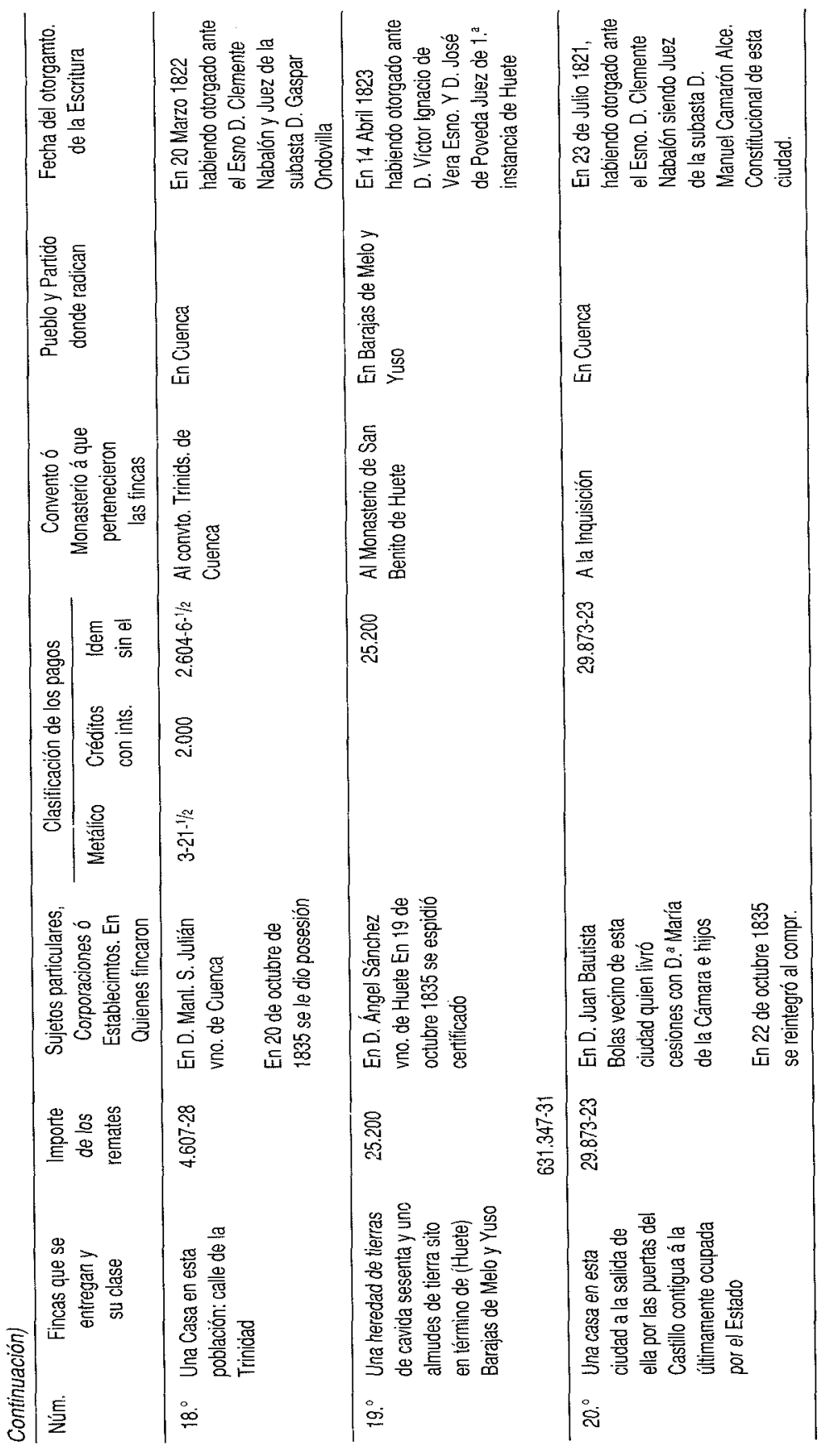


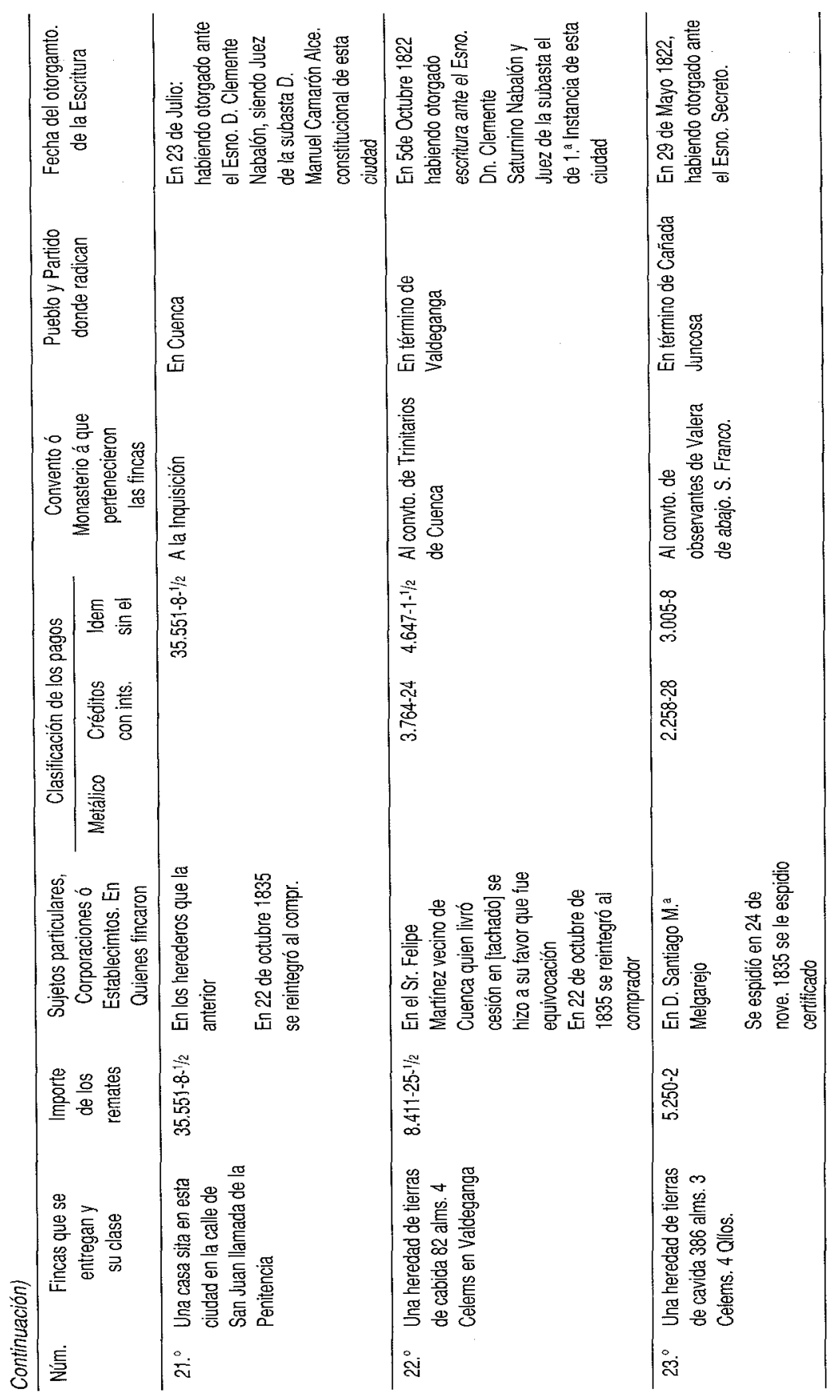




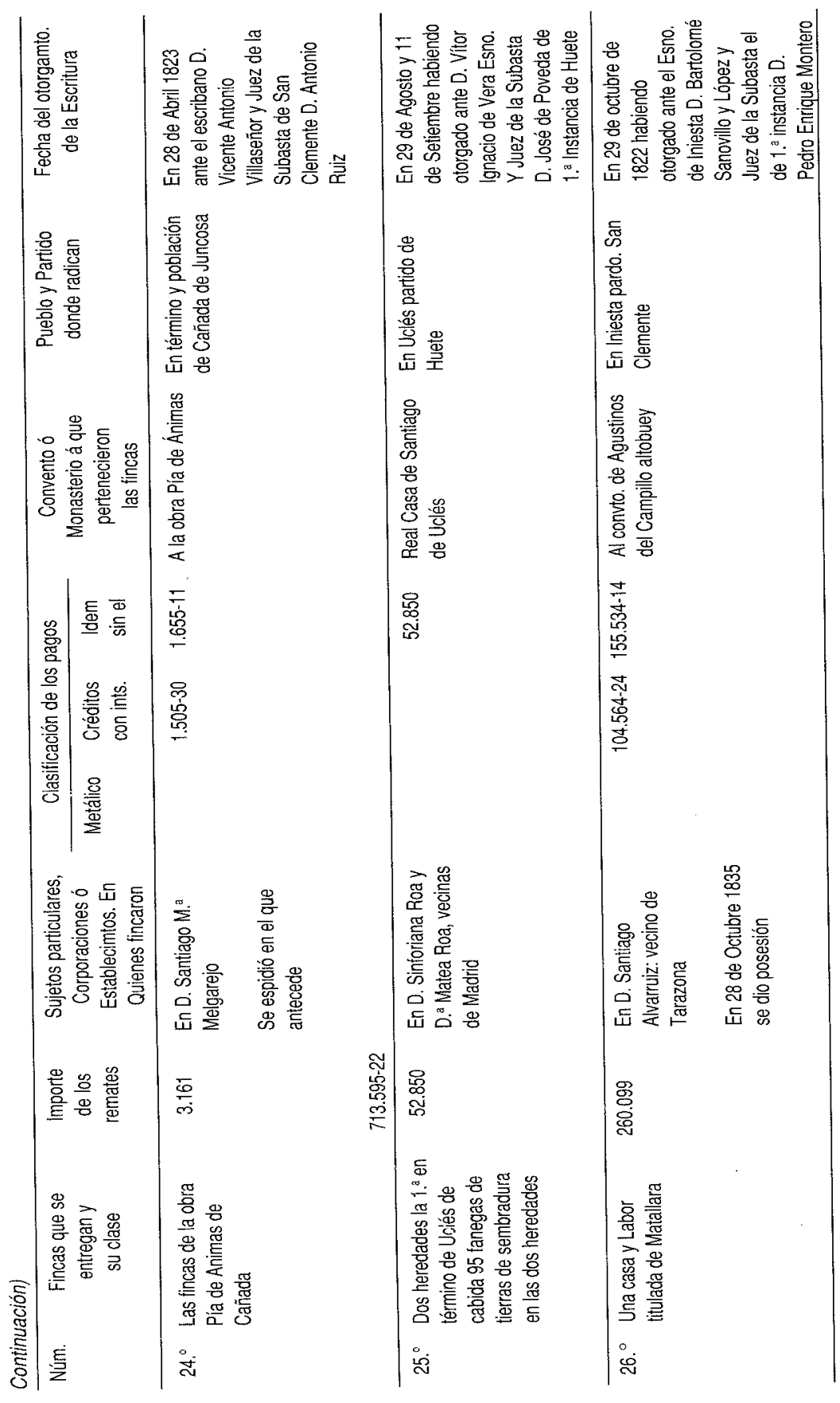




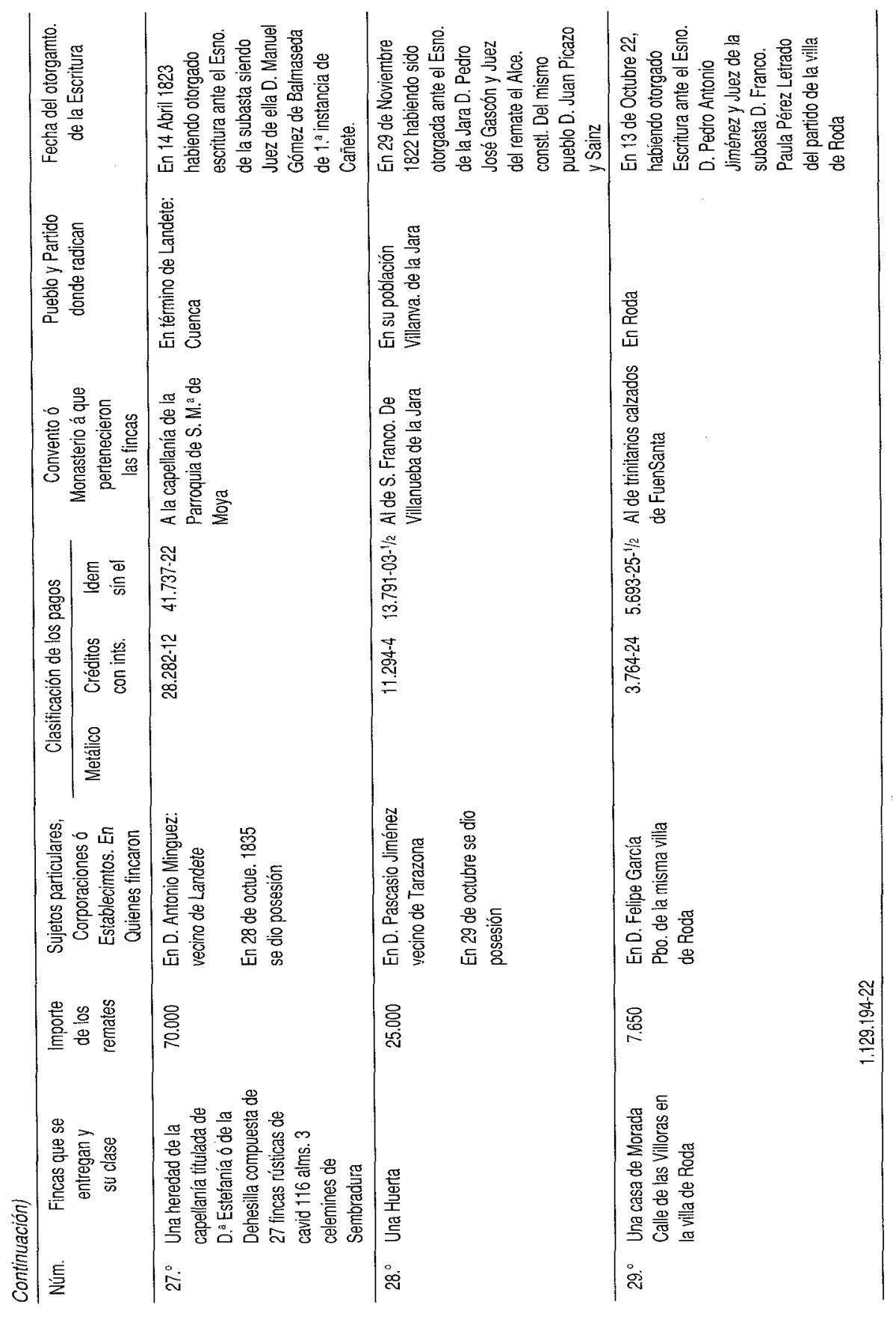




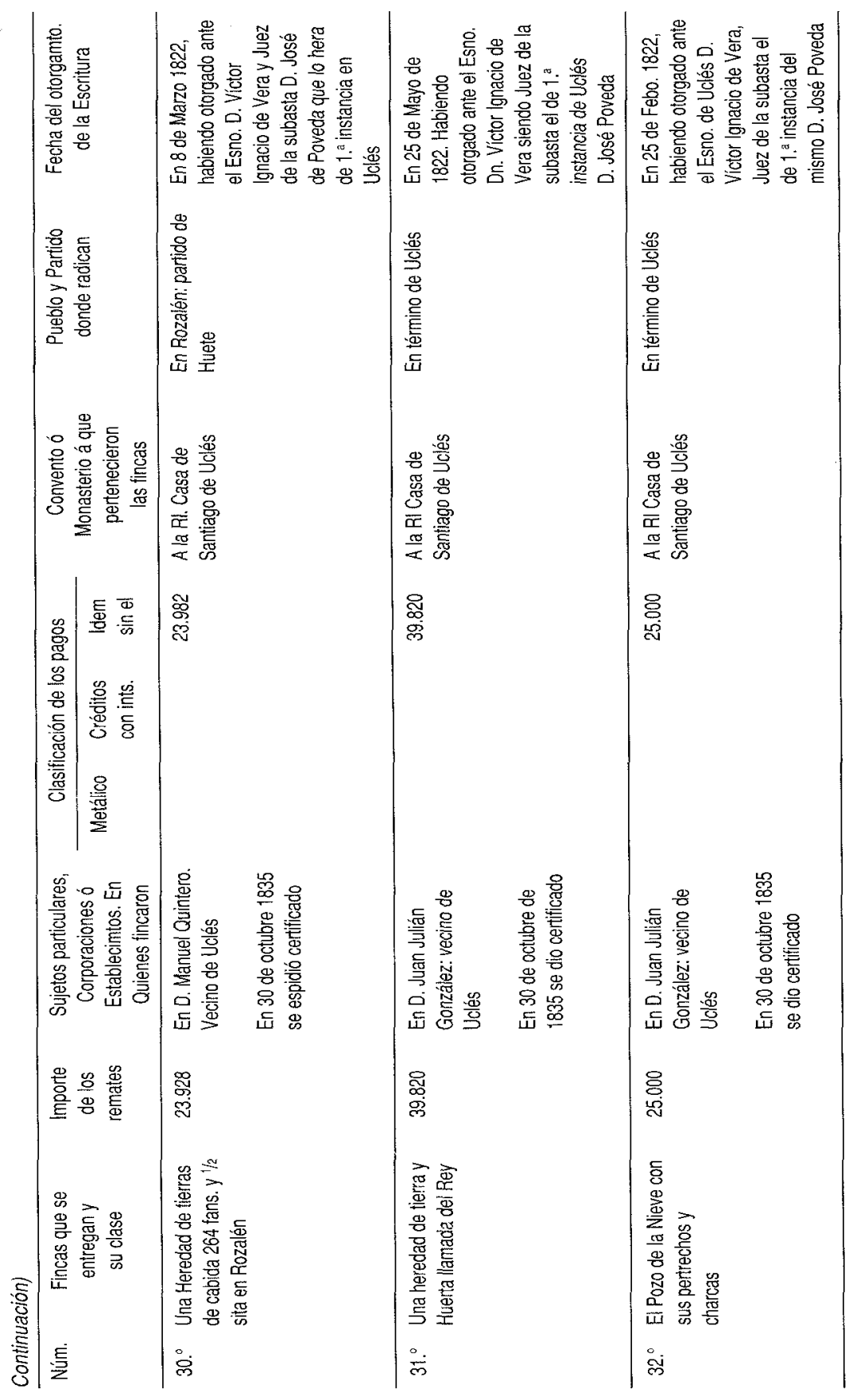




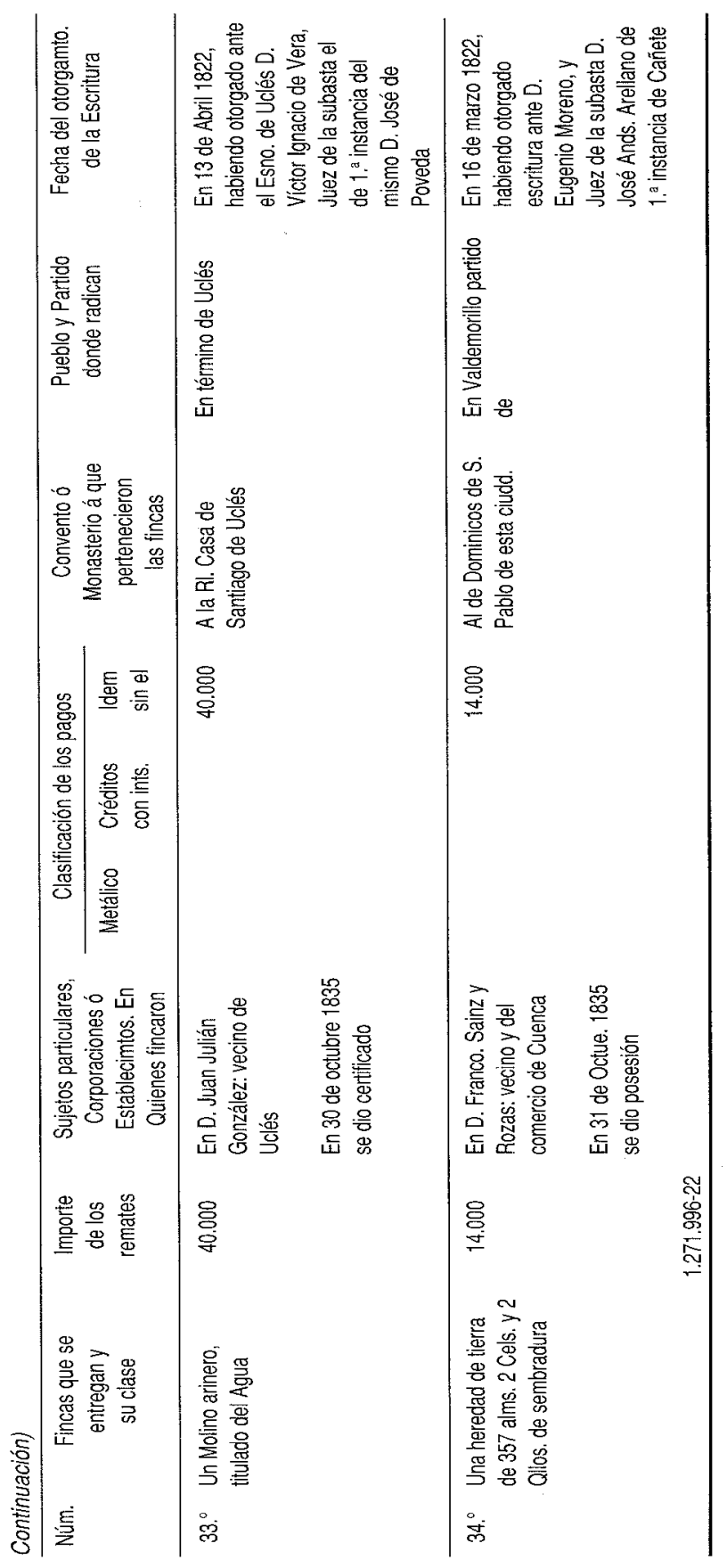

